\title{
MODELING A COMPUTER APPLICATION FOR MANAGEMENT OF MAINTENANCE ACTIVITIES OF UNPAVED ROADS ${ }^{1}$
}

\author{
Ludmília de Souza Dias², Taciano Oliveira da Silva ${ }^{3}$, Heraldo Nunes Pitanga ${ }^{4}$, Renato Vinícius Oliveira \\ Castro $^{5}$, Hélio Garcia Leite ${ }^{6}$ e Carlos Cardoso Machado ${ }^{6}$
}

\begin{abstract}
This study presents a contribution to the modeling of a computer application employing a method of serviceability performance for unpaved roads, aiming the management of maintenance/restoration activities of the primary surface layer. The proposed methodology consisted of field inspections during dry (April to September) and rainy (October to March) periods, during which objective evaluations were performed to survey of defects and their densities and degrees of severity. To aid the functional classification of analyzed road sections and the determination of the defect with major influence on the serviceability of these roads, the method of serviceability performance proposed by Silva (2009)was implemented in the Visual Basic for Applications (VBA) language in Microsoft Excel software. With the use of the computer application proposed it was possible to identify among the defects analyzed in field, through the index of serviceability of the sampling unit per defect type (ISU ${ }_{\text {def }}$ ), which one had the greatest influence on determining the relative serviceability index per road section (IST). The results allow us to conclude that the computer application Road achieved satisfactory results, since the objective evaluation criteria applied to road sections denotes consistency regarding their serviceability.
\end{abstract}

Keywords: Primary surface course; Maintenance management system; Performance model.

\section{MODELAGEM DE UM APLICATIVO COMPUTACIONAL VISANDO AO GERENCIAMENTO DE ATIVIDADES DE MANUTENÇÃO DE ESTRADAS NÃO PAVIMENTADAS}

\begin{abstract}
RESUMO - Esta pesquisa apresenta uma contribuição à modelagem de um aplicativo computacional empregando um método de desempenho de serventia a estradas não pavimentadas, visando ao gerenciamento de atividades de manutenção/restauração de camada de revestimento primário. A metodologia proposta consistiu em inspeções de campo, nos períodos seco (abril a setembro) e chuvoso (outubro a março), em que foram realizadas avaliações objetivas, visando ao inventário de defeitos e respectivas densidades e níveis de severidade. Para auxiliar a classificação funcional dos trechos viários analisados e a determinação do defeito com maior influência sobre a condição de serventia dessas vias, foi implementado, na linguagem Visual Basic for Applications (VBA) no software Microsoft Excel, o método de desempenho de serventia proposto por Silva (2009). Com
\end{abstract}

\footnotetext{
${ }^{1}$ Recebido em 11.08.2014 aceito para publicação em 02.06.2015.

${ }^{2}$ Universidade Federal de São João Del-Rei, Graduada em Engenharia Civil com Ênfase em Estruturas Metálicas, Ouro Branco, Minas Gerais - Brasil. E-mail:<ludmilia_dias@yahoo.com.br>.

${ }^{3}$ Universidade Federal de Viçosa, Departamento de Engenharia Civil, Centro de Ciências Exatas e Tecnológicas, Viçosa, Minas Gerais - Brasil. E-mail: <taciano.silva@ufv.br>.

${ }^{4}$ Universidade Federal de São João Del-Rei, Departamento de Tecnologia em Engenharia Civil, Computação e Humanidades, Ouro Branco, Minas Gerais - Brasil. E-mail: <heraldopitanga@ufsj.edu.br>.

${ }^{5}$ Universidade Federal de São João Del-Rei, Departamento de Ciências Agrárias, Sete Lagoas, Minas Gerais - Brasil. E-mail: <castrorvo@ymail.com>.

${ }^{6}$ Universidade Federal de Viçosa, Departamento de Engenharia Florestal, Viçosa, Minas Gerais - Brasil. E-mail: <hgleite@gmail.com> e $<$ machado@ufv.br>.
} 
o emprego do aplicativo computacional proposto, foi possível identificar entre os defeitos analisados em campo, através do índice de serventia da unidade amostral por tipo de defeito (ISU def $)$, qual foi o que teve maior influência sobre a determinação do índice de serventia relativo por trecho viário (IST). Os resultados possibilitam a conclusão de que o aplicativo computacional Road obteve resultados satisfatórios, visto que o critério de avaliação objetiva aplicado aos trechos viários inspecionados denota coerência quanto às condições de suas serventias.

Palavras-chave: Revestimento primário; Sistema de gerência de manutenção; Modelo de desempenho.

\section{INTRODUCTION}

In Brazil major investments have been made in road system to minimize the shortage of infrastructure given the need for economic growth. Among the investments, stand out that primary road have benefited most, resulting in a relative lack of investment in local secondary roads (OLIVEIRA et al., 2012).

In 2009, these secondary road networks in Brazil had approximately $86 \%$ (1.368 million kilometers $)$ of the Brazilian highway network (ANTT, 2009). Only under the management of municipal governments were approximately 1.235 million kilometers of unpaved roads until 2009. As to the jurisdiction of unpaved roads, at a Brazilian level there are about $90.2 \%$ of municipal, $8.8 \%$ of state and $1.0 \%$ of federal roads. From the data presented, one can evaluate the possible consequences of insufficient allocation of resources in this road system.

Despite the large size of Brazil, which undoubtedly demands large amounts of financial resources, both for deployment and for conservation, and due to its social and economic importance, there is a significant lack of research and technological advances in the state of the art for unpaved roads (SILVA et al., 2011), including rural and forest roads.

The importance of forest roads has been emphasized in several studies. Corrêa et al. (2006) point out that the forest road network must meet comprehensively the social aspects, have technical feasibility and set up seeking the best route with the lowest cost of deployment and maintenance, in order to reduce the harmful effects to the environment.

According to Machado (2013), investments allocated to the infrastructure of these roads allow to increase productivity levels, and provide social benefits to communities by providing access to markets, services, jobs and information. The author highlights that improvement programs of forest roads reduces the costs of transportation and agricultural products, increasing the competitiveness of agricultural production, but also improving the quality of life of the surrounding communities.

Lopes et al. (2002) report that the requirements in terms of requests of forest roads have been improved due to the increased volume of traffic of high tonnage vehicles, the increase in transport distances in lowquality roads, the need for trafficability through out the year and the need for roads with longer life, which reinforces the importance of implementing an effective management for their maintenance.

In this context, the conduction of this study is justified by the fact that in Brazil there are few studies aimed at developing computer systems for managing maintenance activities of unpaved road networks within municipalities and private companies.Among these studies, Emmert et al. (2010) proposed the use of geoprocessing technologies in the acquisition, handling, spatial distribution and visualization of data of quality of forest roads, and in the production of thematic maps, with the identification of critical points for timber transport, supporting the development of regular preventive maintenance program.

In order to minimize costs and traffic disruptions, Oliveira et al. (2013) present a method used to subsidize the generation of a database to test the efficiency of the use of artificial neural networks in the management of forest roads, through the identification and measurement of the main defects of these roads.

Pinto (2009) proposes the use of "Relational Unified Process" tool in guiding the management of unpaved forest roads, which encompasses policy suggestions and alternative maintenance measures, with decision trees proposals to select these interventions according to the severity and extent of the defects identified in the field.

In this way, considering the importance of the topic, this research presents a contribution to the 
modeling of a computer application using a method of serviceability performance developed by Silva (2009), aiming the management of maintenance activities of unpaved roads. Importantly, the proposed methodology applies to any type of unpaved road (rural or forest, for example), even if it's different types are distinct by traffic demand level.

\section{MATERIALAND METHODS}

\subsection{Study area}

The municipality of Ouro Branco has an area of $260,766 \mathrm{~km}^{2}$, is in the microregion of Conselheiro Lafaiete in the state of Minas Gerais, $95 \mathrm{~km}$ far from Belo Horizonte, Brazil, with average latitude and longitude of $20^{\circ} 31^{\prime} 15^{\prime \prime} \mathrm{S}$ and $43^{\circ} 41^{\prime} 31^{\prime \prime} \mathrm{W}$, respectively, at an average elevation of $1,100 \mathrm{~m}$. It borders with the municipalities of Congonhas, Conselheiro Lafaiete, Itaverava and OuroPreto.

\subsection{Experimental road sections}

During field investigations three unpaved back roads locatedin Road Real (Ouro Branco/Ouro Preto), district of Água Limpa, with 4.3 kilometer shave been traveled; the District of Água Limpa-district of Cristais with $1.5 \mathrm{~km}$ and the district of Cristais-district of Cristalino, with $3.2 \mathrm{~km}$, approximately.

\subsection{Methodof service ability performance}

The method of serviceability performance proposed by Silva (2009), based on density and severity of defects, and related to the relative serviceability index per road section (IST) has been changed in the functional classification scale to meet mathematical criteria of the computer system called Road, proposed to contribute to the management of maintenance activities of unpaved road networks.

This method is linked to the prediction of the loss of the serviceability condition, when related to the density and level of severity of defects representative of Brazilian unpaved road networks.

This is a method for the evaluation and management of maintenance activities of unpaved roads.

Its development consisted basically of three steps: steps 1 and 2 resulted from field inspections and calculations of relative serviceability indices per road stretch (IST), respectively. Step 3 was the development of a computer device compatible with the management of maintenance activities of unpaved roads, due to loss of the serviceability condition of the surface wearing.

\subsection{Objective assessment of the condition of unpaved roads}

The condition of the surface wearing may be related to factors such as structural integrity, structural capacity, roughness and degree of deterioration.

Direct measurements of these factors require expensive equipment and highly trained manpower. However, the evaluation of these factors can be made by observation and measurement of defects of surface wearing, which can be represented by the index of relative serviceability per road stretch (IST).

The numerical scale of the IST used in this study was changed from that presented by Silva (2009) to meet the mathematical criteria for weighting different degrees of severity of all defects considered in the inspected roads.

As a numerical indicator, IST ranged from 0 to 7.75 and indicated the integrity of the road and operating condition of its surface wearing. In general, this index was correlated with the level of need for maintenance and repair of the road.

The scale of functional classification of the index indicates that IST to IST in the range of ( 0.00 to 1.25$)$ functional classification is excellent; of ( 1.26 to to $2.55)$ is good; of (2.56 to 3.85$)$ is fair; (3.86 to 5.15 ) is poor; of (5.16 to 6.45) is very poor and (6.46 to $7.75)$ is failed.

\subsection{Workingmethod}

The need for division of unpaved roads inspected in road stretches was due to non-uniformity of the geometric features of these roads.

Aiming to fulfill this need, it was opted for the criteria established by the method of serviceability performance, proposed by Silva (2009), which establishes road stretcheswith length between 750 and 1,000 meters, containing at least two sampling units, which are 50 meters long.

With these criteria, the unpaved roads inspected were divided into 11 road stretches totaling 22 sampling units.

Revista Árvore, Viçosa-MG, v.39, n.4, p.723-731, 2015 
The roads stretches 1, 2, 3, 4 and 5 of Road Real (Ouro Branco/Ouro Preto) - district of Água Limpa present length of 860 meters each; the district of Água Limpa- district of Cristais presents for roads stretches 1 and 2, length of 750 meters each and the district of Cristais - district of Cristalino, presents, for roads stretches 1, 2, 3 and 4, length of 800 meters each.

The sampling units were considered as the smallest division of the inspected roads, which are the portions suitable for the survey of defects, in order to determine the condition of the surface wearing.

\subsection{Inspection of the unpaved roads}

The inspection of the unpaved roads involved the inventory of defects found in 22 sampling units during the dry (April to September) and rainy (October to March) periods.

This inspection was performed by writing down in inspection forms the numerical values of the areas of sampling units and the number of occurrence of defects, with their respective attributes of density and severity, according to Table 1 .

\subsection{Calculation of IST from field inspections}

To optimize the calculation of the IST, it was developed a computer application called Road, based on the method of serviceability performance proposed by Silva (2009), which enabled to functionally classify the inspected road sections and identify the characteristic defect of greatest influence in determining this index.

However, to determine the impact of each defect, it was necessary to calculate the density of each defect in the sampling units. The calculation of the index of relative serviceability per road stretch (IST) consisted of the following steps:

- Determination of surface defect density per sampling unit (DSR def $)$, which is the ratio between the areas, length or amount of such defect by the sampling unit area, according to Equation 1.

$$
\mathrm{DSR}_{\text {def }}=\frac{f_{a}}{\mathrm{~A}_{\mathrm{u} . \mathrm{a}}}
$$

Where in: $D_{S R}$ is the surface defect density per sampling unit, $f_{a}$ is the absolute frequency of the defect in the sampling unit, and $\mathrm{A}_{\mathrm{u} . \mathrm{a}}$ is the area of the sampling unit in $\mathrm{m}^{2}$.

- Determination of the values of $f_{p}$ and DSR def for each type of defect, the sum of the product between these variables consists of an indicative value of the relative severity of the sampling unit per defect, expressed as values with two decimal places ranging from 0.00 to 7.75, so-called index of serviceability of the sampling unit per defect type (ISU $\mathrm{Ief}_{\text {) }}$ ) according to Equation 2.

$$
\mathrm{ISU}_{\mathrm{def}}=\sum \mathrm{f}_{\mathrm{p}} \cdot \mathrm{DSR}_{\mathrm{def}}
$$

Table 1 - Model of inspection form used in sampling units.

Tabela 1 - Modelo de folha de inspeção utilizada nas unidades amostrais.

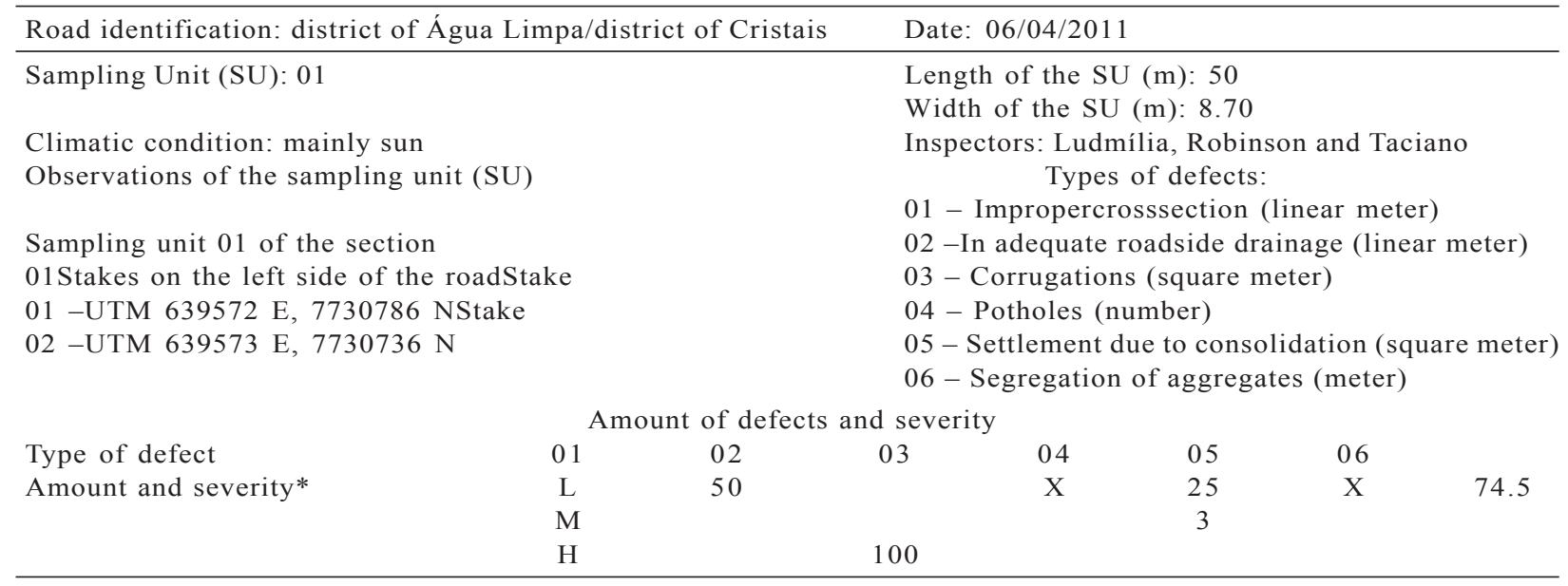

* Severity attributes are: L: Low, M: Medium and H: High.

Revista Árvore, Viçosa-MG, v.39, n.4, p.723-731, 2015 
Where in: $\mathrm{ISU}_{\text {def }}$ is the index of serviceability of the sampling unit per defect; $f_{p}$ is the weighting factor of the attribute of severity of each type of defect found in the sampling unit; and DSR ${ }_{\text {def }}$ is the surface defect density per sampling unit.

- Determination of the value of the relative serviceability index of the sampling unit, which is the ratio between the sum of the values of ISU $U_{\text {def }}$ per type of defect and the number of types of defects observed in the sampling unit, according to Equation 3.

$$
\mathrm{ISU}=\frac{\mathrm{ISU}_{\mathrm{def}}}{\mathrm{n}}
$$

Where in: ISU is the relative serviceability index per he sampling unit; ISU ${ }_{\text {def }}$ is the sum of values of ISU $_{\text {def }}$ of the sampling unit; and $\mathrm{n}$ is the number of types of defects verified in the sampling unit inspected.

- Calculation of indices of relative serviceability per road stretch (IST), according to Equation 4.

$$
\mathrm{ISR}=\frac{\sum \text { ISUu.a.n }}{\mathrm{n}}
$$

Where in: IST is the relative serviceability index per road stretch; $\mathrm{ISU}_{\text {u.a.n }}$ are indices of relative serviceability of the sampling units per road stretch inspected and $\mathrm{n}$ is the number of sampling units per road stretch.

\subsection{Computer application to implement the proposed methodology}

In this study, we developed an application of the proposed methodology. The computer application Road was implemented in Visual Basic for Applications (VBA) in Microsoft Excel, using equations of service ability performance developed by Silva (2009).

The computer application Road presents as outputs the prediction of maintenance/restoration activities through functional classification of road stretch and the type of defect that has greater influence on the condition of serviceability of the road stretch inspected.

In further studies, with the improvement of this computer application other results can be implemented for the output data, such as the percentage of areas containing defects with high density and severity, types of interventions to be implemented (routine or periodic maintenance) and presentation of the implementation cost of maintenance/ restoration, depending on the type, density and severity of the defect of greater influence on the decline of serviceability condition of the road section.
The input data of the computer application Road are divided into data on the number of inspected roads, road stretch and evaluated sampling units and their respective identifications, besides the types of defects and their densities and severities.

The input data of this application are entered in two worksheets, the first named "input", with data on unpaved roads to be inspected, and another, called "data", which present the types of defects with their densities and severities per sampling unit.

The worksheet named "results" shows the values of indices required for the functional classification of the road stretches according to defects of surface wearing for each inspection period. The data required to run the computer application Road should be the types of defects and their densities and severity per sampling unit.

\section{RESULTS}

Using the proposed computer application, among the defects analyzed in the field, it was identified by means of the index of serviceability of the sampling units per type of defect (ISU def ), which one had the greatest influence on the determination of the index of relative serviceability per road stretch (IST).

Figure 1 presents part of the spreadsheet "results" of the computer application Road for the calculation of the IST, highlighting the functional classification for the rainy period, of the two sampling units of the section 1 of the unpaved road that connects the Road Real (Ouro Branco - Ouro Preto) to the district of Água Limpa in the municipality of Ouro Branco.

The program displays the spreadsheet and the frame road stretches to the right side where you can choose one of the road sanalyzed, showing that the classification obtained each section, as well as knowing which defect presented with greater frequency.

Figure 2 displays the spreadsheet and the box road stretch on the right, where one can choose one of the roads analyzed, with rankings that each section obtained, and know which defect had greater frequency. As presented in five sections of the road 1, the defect 2 (Inadequate road side drainage) was the surface defect with highest frequency.

Figure 3 shows the value sob tained from ISU inspected sample units, according to the method proposed by Silva (2009).

Revista Árvore, Viçosa-MG, v.39, n.4, p.723-731, 2015 


\begin{tabular}{|c|c|c|c|c|c|c|c|c|c|c|c|c|}
\hline ID & Rodovia & Trecho & Unid. Amostral & Area U.A. $\left(\mathrm{m}^{2}\right)$ & Defeito & $\mathrm{fa}$ & $\mathrm{fp}$ & DSRde & ISUdef: & ISU & IST & Classificação \\
\hline 1 & DAL & 1 & 1 & 467,5 & S.T.I. & 50 & 1 & 0,11 & 0,11 & & 1,07 & Excelente \\
\hline 1 & DAL & 1 & 1 & 467,5 & Dren. Inadequada & 100 & 3 & 0,21 & 0,64 & & 1,07 & Excelente \\
\hline 1 & DAL & 1 & 1 & 467,5 & Corrugaçōes & 0 & 0 & 0,00 & 0,00 & & 1,07 & Excelente \\
\hline 1 & DAL & 1 & 1 & 467,5 & Buracos & 28 & 1 & 0,06 & & & 1,07 & Excelente \\
\hline 1 & DAL & 1 & 1 & 467,5 & Buracos & 3 & 2 & 0,01 & & & 1,07 & Excelente \\
\hline 1 & DAL & 1 & 1 & 467,5 & Buracos & 1 & 3 & 0,00 & 0,08 & & 1,07 & Excelente \\
\hline 1 & DAL & 1 & 1 & 467,5 & Trihas de roda & 0 & 0 & 0,00 & 0,00 & & 1,07 & Excelente \\
\hline 1 & DAL & 1 & 1 & 467,5 & Segreg. de agregado & 0 & 1 & 0,00 & 0,00 & & 1,07 & Excelente \\
\hline 1 & DAL & 1 & 1 & 467,5 & Erosão & 0 & 0 & 0,00 & 0,00 & 0,83 & 1,07 & Excelente \\
\hline 1 & DAL & 1 & 2 & 397,5 & S.T.I. & 50 & 1 & 0,13 & 0,13 & & 1,07 & Excelente \\
\hline 1 & DAL & 1 & 2 & 397,5 & Dren. Inadequada & 100 & 3 & 0,25 & 0,75 & & 1,07 & Excelente \\
\hline 1 & DAL & 1 & 2 & 397,5 & Corrugações & 0 & 0 & 0,00 & 0,00 & & 1,07 & Excelente \\
\hline 1 & DAL & 1 & 2 & 397,5 & Buracos & 70 & 1 & 0,18 & & & 1,07 & Excelente \\
\hline 1 & DAL & 1 & 2 & 397,5 & Buracos & 36 & 2 & 0,09 & & & 1,07 & Excelente \\
\hline 1 & DAL & 1 & 2 & 397,5 & Buracos & 10 & 3 & 0,03 & 0,43 & & 1,07 & Excelente \\
\hline 1 & DAL & 1 & 2 & 397,5 & Trihas de roda & 0 & 1 & 0,00 & 0,00 & & 1,07 & Excelente \\
\hline 1 & DAL & 1 & 2 & 397,5 & Segreg. de agregado & 0 & 0 & 0,00 & 0,00 & & 1,07 & Excelente \\
\hline 1 & DAL & 1 & 2 & 397,5 & Erosão & 0 & 0 & 0,00 & 0,00 & 1,31 & 1,07 & Excelente \\
\hline
\end{tabular}

Figure 1- Spreadsheet "Results" of the computer application Road.

Figura 1 - Planilha eletrônica dos "Resultados" do aplicativo computacional Road.

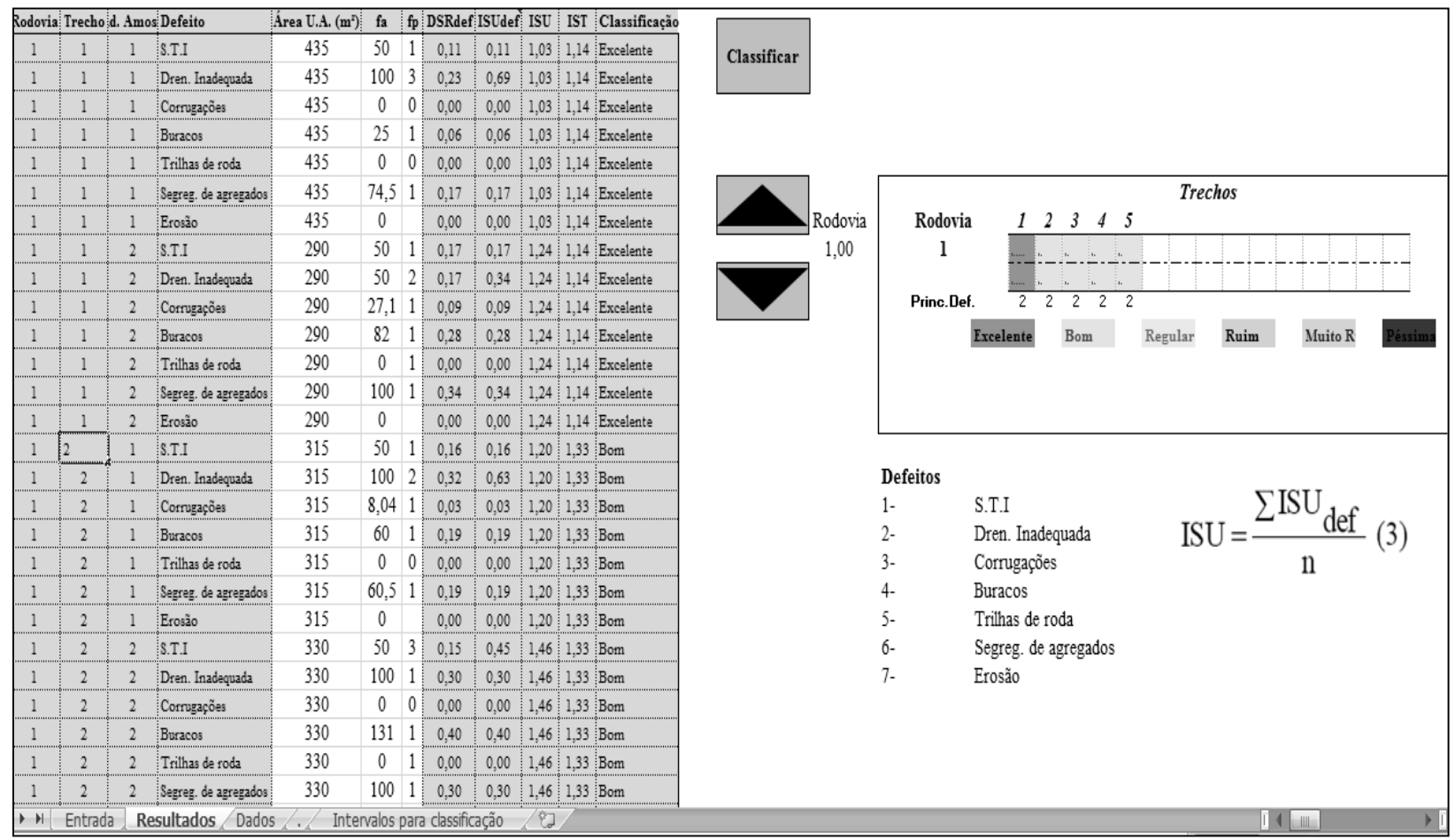

Figure 2 - Spreadsheet "Results" with the classification of four stretches of one of the roads examined.

Figura 2 - Planilha eletrônica dos "Resultados" com a classificação dos quatro trechos de uma das rodovias investigadas.

Revista Árvore, Viçosa-MG, v.39, n.4, p.723-731, 2015 


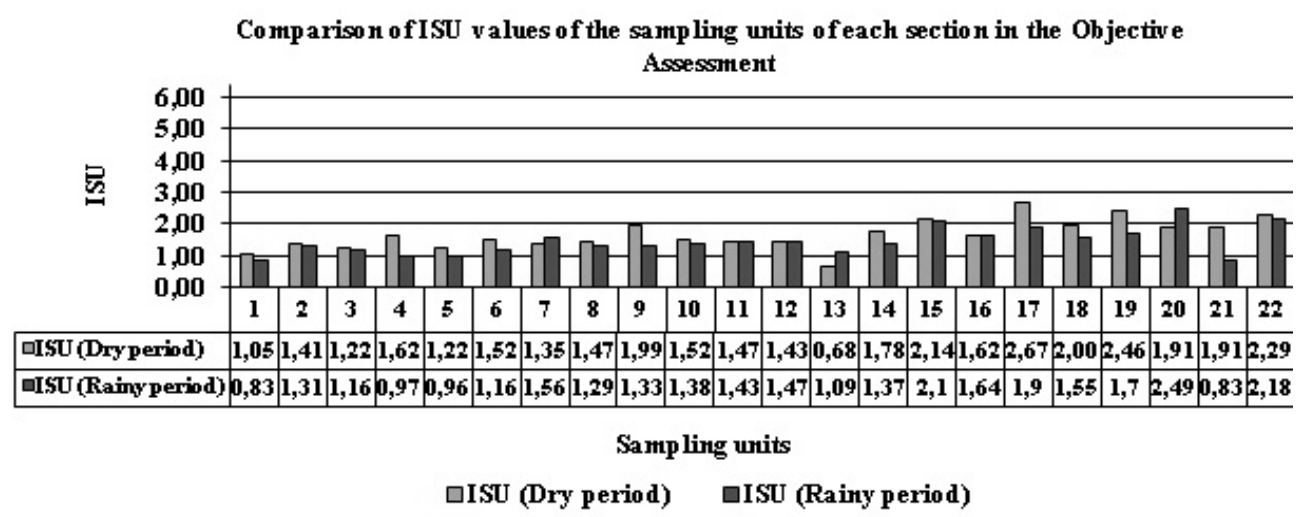

Figure 3 - ISU values obtained from sampling units of the road sections inspected. Figura 3 - Valores de ISU obtidos das unidades amostrais dos trechos viários inspecionados.

The first road stretch of unpaved roads that connects Road Real (Ouro Branco-Ouro Preto) to the district of Água Limpa and from the district of Cristais to the district of Cristalino showed IST values of 1.23 for the dry period, being functionally classified as in excellent serviceability condition. The other road sections of inspected unpaved roads showed IST values between 1.26 and 2.55 and therefore classified as in good serviceability condition, according to Figure 4.

\section{DISCUSSION}

The information about the serviceability conditions of the surface wearing of unpaved roads obtained by the method of performance and computer application proposed were useful for the identification of priority areas for purposes of maintenance activities.

The Secretariat of Public Works and Services of the city hall of Ouro Branco, state of Minas Gerais, performs scraping during the dry period, in order to adjust leveling and shaping the cross section of the platforms of unpaved roads in the rural area ofthe municipality.

After this maintenance operation, it is customary to improve the existing primary surface course layer with crushed and compacted steel slag, which contributes to the characterization of some investigated defects, such as segregation of aggregates and inadequate drainage, since part of the material accumulates in the gutters due to influence of traffic.
In rainy periods, scraping is not conducted, but weeding and the maintenance of bearing surface of the unpaved roads are made without any analysis of the influence of the type and severity of the defects on the condition of serviceability of these roads.

The objective inspection of road sections and sampling units inspected for the dry period indicated the inadequate drainage as the most influential defect in determining the functional classification of unpaved roads, possibly by accumulation of ground steel slag on the surface drainage devices. In some road sections, for lack of a routine maintenance activity, the gutters are in terrible condition to meet the demand from rainfall that may come to precipitate on the platform of the road.

The objective inspection of road stretches and sampling units during the rainy period pointed out the inadequate drainage again as the most influential defect in determining the functional classification of serviceability conditions of unpaved roads.

The conservation interventions routinely performed by the Secretariat of Public Works and Services of the city hall of Ouro Branco were only shaping the cross section of platforms in such roads, with improvement of primary surface course layer with crushed and compacted steel slag without repairing surface drainage devices.

At the time of objective inspections during the rainy period, the initial sections of the unpaved road that connects the Road Real (Ouro Branco-OuroPreto) 


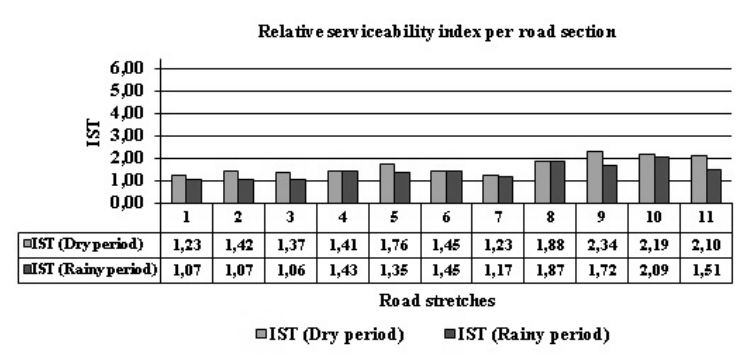

Figure 4- IST values of the inspected road stretches on the dry and rainy periods.

Figura 4 - Valores de IST dos trechos viários inspecionados nos períodos seco e chuvoso.

to the district of Água Limpa received treatment to improve the primary surface course layer with crushed steel slag, obtaining IST values at 1.07 for the functional classification of the first two road sections of this road, and the third with IST equal to 1.06 , categorizing these sections as in excellent condition of serviceability.

The second road stretch of the unpaved road that links the districts of Cristais and Cristalino was also functionally rated as in excellent serviceability condition reaching an IST value of 1.17 , although they had not received improvement in its primary surface layer. The others portions of this unpaved road attained IST values between 1.26 and 2.55 , thus functionally classified as in good condition of serviceability.

Due to the similarities between rural roads and forest roads (Machado, 2013), mainly evidenced by having no type of coating in their respective bearing areas and because they are subjected to common deterioration mechanisms, the proposed method is applicable to the management of forest roads, and therefore represents a good and practical decisionmaking tool to ensure, over the expected service time, the appropriate functional performance of unpaved roads subjected to traffic of vehicles typical of forest exploitation undertakings.

\section{CONCLUSION}

The functional classification of the road sections inspected as a function of serviceability conditions of their surface wearing derives from the representative ness of objective evaluation of their sampling units.
The determination of the performance of an unpaved road is not a simple task, since many predictive models are designed for paved roads. Nevertheless, the adoption of a serviceability performance model for unpaved roads proves to be a useful tool, but it needs to be calibrated over time by the managers, municipalities and private enterprises, aiming to adapt it to different situations.

The serviceability performance model proposed by Silva (2009) and implemented in the computer application Road achieved satisfactory results, once the objective evaluation criterion applied to the inspected road stretches expresses consistency regarding the conditions of their serviceability, being consistent with the field reality of primer coating layers of unpaved roads analyzed.

\section{ACKNOWLEDGEMENTS}

To the Foundation for Research Support of the State of Minas Gerais - FAPEMIG for the financial support to the first author, to Federal University of São João Del Rei (UFSJ) for logistical support in the inspections of unpaved roads.

\section{REFERENCES}

\section{AGÊNCIANACIONAL DE TRANSPORTES} TERRESTRES - ANTT. Anuário Estatístico dos Transportes Terrestres. Brasília: 2009.

CORRÊA, C.M.C.; MALINOVSKI, J.R.; ROLOFF, G. Bases para planejamento de rede viária em reflorestamento no sul do Brasil. Floresta, v.36,n.2,p.277-286,2006.

EMMERT, F.; PEREIRA, R. S.; REZENDE, A.V.; ENCINAS, J. M. I. Geoprocessamento como ferramenta de apoio à gerência de pavimentos em estradas florestais. Ciência Florestal, v.20, n.1, p.81-94, 2010.

LOPES, E.S.; MACHADO, C.C.; SOUZA, A.P. Classificação e custos de estradas em florestas plantadas na região sudeste do Brasil. Revista Árvore, v.26, n.3, p.329-338, 2002.

MACHADO, C.C. Construção e conservação de estradas rurais e florestais. Viçosa, MG: SIF, 2013. 441p. 
OLIVEIRA, R. J.; GLERIANI,J.M.; MACHADO, C. C.; PEREIRA, R. S.; CORDEIRO, S.A. Análise da trafegabilidade em estradas florestais utilizando métodos computacionais. Revista Árvore, v.37, n.2, p.355-360, 2013.

PINTO, P.R.R. Contribuição à modelagem de um sistema de gerenciamento da manutenção de rodovias não pavimentadas em empreendimentos de exploração florestal. 2009. 162f. Dissertação (Mestrado em Engenharia Civil) - Universidade Federal do Rio Grande do Sul, Porto Alegre, 2009.
SILVA, T.O. Estudo de estradas não pavimentadas da malha viária do município de Viçosa-MG. 2009. $119 f$. Tese (Doutorado em Engenharia Civil) Universidade Federal de Viçosa, Viçosa, MG. 2009.

SILVA, T. O.; CARVALHO, C. A. B.; LIMA, D. C.; CALIJURI, M. L.; MACHADO, C. C.

Influência do tráfego de veículos comerciais em rodovias vicinais não pavimentadas: estudo de caso aplicado à VCS 346, Viçosa, MG. Revista Árvore, v.35, n.3, p.539-545, 2011. 